\title{
RYZYKO I ZARZĄDZANIE RYZYKIEM W JEDNOSTKACH SAMORZĄDU TERYTORIALNEGO
}

\begin{abstract}
Od setek lat niepewność i ryzyko są nieodłącznym elementem każdej działalności człowieka zarówno w sferze prywatnej, jak i w sferze gospodarczej. Zagadnienia te od ponad stu lat stanowią przedmiot szczegółowych badań w różnych dyscyplinach naukowych. W naukach ekonomicznych pierwotnie główne kierunki badań związane były z występowaniem ryzyka w działalności podmiotów gospodarczych. Do dziś znaczny odsetek społeczeństwa właśnie tam upatruje możliwości występowania tego zjawiska.

W literaturze przedmiotu można odnaleźć wiele różnych definicji tego zjawiska w zależności od obszaru sytuacji decyzyjnej i sposobu jego analizy. Tak więc w teorii zarządzania przyjęto, że ryzyko stanowi możliwość nieosiagnnięcia założonego celu. W XX wieku w Stanach Zjednoczonych pojawiła się nowa dyscyplina naukowa określana mianem zarządzania ryzykiem. Pierwotnie miała ona stanowić jedynie element zarządzania ubezpieczeniami. Aktualnie zarządzanie ryzykiem, zorientowane na ograniczanie niepewności, jest procesem, który na trwałe został powiązany z prawie wszystkimi sferami działalności człowieka. Kolejną taką sfera, która jeszcze na początku XXI wieku nie była analizowana pod kątem związanego z jej działalnością ryzyka, jest działalność jednostek samorządu terytorialnego.

W artykule zaprezentowano zagadnienia związane $\mathrm{z}$ problematyką ryzyka w jednostkach samorządu terytorialnego. Zagadnienia te w polskich warunkach stały się przedmiotem szczegółowych badań w ostatnim okresie w związku z wprowadzeniem przepisów nakładających na jednostki samorządu terytorialnego podjęcia działań w zakresie zarządzania ryzykiem. Wcześniej jednostki samorządowe miały jedynie obowiązek podjęcia działań związanych zminimalizowaniem ryzyka finansowego poprzez wdrożenie standardów i systemowego podejścia do kontroli zarządczej. W pierwszej części artykułu przedstawiono definicję i klasyfikację ryzyka występującego w jednostkach samorządu terytorialnego. W dalszej części omówiono zagadnienia związane z zarządzaniem ryzykiem w tych podmiotach.
\end{abstract}

Słowa kluczowe: ryzyko, zarządzanie ryzykiem, jednostka samorządu terytorialnego

\section{WPROWADZENIE}

Zjawisko ryzyka towarzyszy wszystkim działaniom podejmowanym przez człowieka od początku istnienia cywilizacji. Jest to pojęcie, którego nie można jednoznacznie zdefiniować. Wiąże się to między innymi z tym, że wraz z rozwojem cywilizacji pojawiają się nowe formy aktywności człowieka, które stwarzają mu różnego rodzaju szanse i zagrożenia. A tym samym dają możliwość badaczom tego zjawiska do formułowania nowych definicji dostosowanych do specyfiki tych zjawisk.

\footnotetext{
Dr inż. Mirosław Sołtysiak, Zakład Finansów i Bankowości, Wydział Zarządzania, Politechnika Rzeszowska, Al. Powstańców Warszawy 8, 35-959 Rzeszów, tel.: 1786519 15, e-mail: miroslaw@prz.edu.pl
} 
Występowanie ryzyka zazwyczaj jest kojarzone z działalnością gospodarczą lub innymi - poza gospodarczymi - formami aktywności człowieka. Rzadziej zjawisko to rozpatrywane jest w odniesieniu do działalności podmiotów, które mają pełnić w stosunku do obywateli funkcję służebną, czyli na przykład jednostek samorządu terytorialnego. W opinii wielu osób utrwaliło się przekonanie, że państwo nie może „,zbankrutować”, a więc nie mogą również ,zbankrutować” organy ${ }^{3}$, które go reprezentują. Takie rozumowanie części społeczeństwa mogą potwierdzić wyniki przeprowadzonych badań ankietowych $^{4}$, w których $33 \%$ ankietowanych stwierdziło, że z działalnością jednostek samorządu terytorialnego nie jest związany żaden rodzaj ryzyka. Wyniki te są tym bardziej interesujące, że zostały uzyskane w momencie, kiedy już od pewnego czasu obowiązują usta$\mathrm{wy}^{5}$ oraz wytyczne dotyczące postępowania $\mathrm{w}$ sprawie zarządzania ryzykiem $\mathrm{w}$ jednostkach samorządu terytorialnego ${ }^{6}$.

Celem artykułu jest zaprezentowanie zagadnień związanych z problematyką ryzyka oraz zarządzania ryzykiem w jednostkach samorządu terytorialnego. Dodatkowo dąży się do wskazania, jak te zjawiska są postrzegane przez członków lokalnych społeczności.

\section{RYZYKO W JEDNOSTKACH SAMORZĄDU TERYTORIALNEGO}

Literatura przedmiotu z zakresu problematyki ryzyka, chociaż stosunkowo obszerna, nie przedstawia jednak ścisłej i jednoznacznej definicji ryzyka, która mogłaby być wykorzystywana do opisywania tego zjawiska niezależnie od tego, jakiego obszaru działalności ludzkiej dotyczy.

\footnotetext{
${ }^{2}$ Bankructwa państwa nie można oczywiście porównywać z bankructwem podmiotu gospodarczego. Wiąże się ono z odmową zwrotu zaciągniętych pożyczek, która jednak nie pociąga za sobą ani likwidacji państwa, ani licytacji jego mienia. Zjawisko to występowało już w starożytnej Grecji. W czasach nowożytnych z problemem tym spotykamy się XVI i XVII w., kiedy Hiszpania i Francja odmówiły spłaty swoich długów. Nasilenie tego zjawiska nastąpiło w XX w. W latach osiemdziesiątych XX w. również Polska nie spłacała regularnie swoich długów.

${ }^{3}$ Zgodnie z artykułem 6 punktem 2 ustawy „Prawo upadłościowe i naprawcze” jednostka samorządu terytorialnego nie może ogłosić upadłości. Nie oznacza to jednak, że działalność jednostek samorządowych nie jest narażona na ryzyko. Ministerstwo Administracji i Cyfryzacji w raporcie „Ocena sytuacji samorządów lokalnych” podaje, że w 2011 r. 32 jednostki samorządu terytorialnego (jst.) (tj. 31 gmin i 1 powiat) przekroczyło ustawowy limit 60-proentowego zadłużenia w stosunku do dochodów, a 55 jst. nie zachowało reguły zrównoważania działalności bieżącej z art. 242 „Ustawy z 27 sierpnia 2009 r. o finansach publicznych”. Ponadto stwierdzono, że w 2011 r. - 108 jst. a w 2012 r. - 48 jst. nie było wstanie spełnić wymogów artykułu 243 „Ustawy z 27 sierpnia 2009 r. o finansach publicznych” (przepis wchodzi w życie 1 stycznia 2014 r.). Należy również nadmienić, że z końcem 2013 r. wprowadzono zmiany w tym artykule mające na celu umożliwienie samorządom w nowej perspektywie unijnej realizację inwestycji z wykorzystaniem funduszy unijnych bez obaw, że spowoduje to ryzyko niespełnienia dopuszczalnego wskaźnika, a tym samym brak możliwości uchwalenia budżetu przez właściwy organ.

Nie we wszystkich państwach na świecie przepisy prawne, podobnie jak w Polsce, regulują brak możliwości upadłości jednostki samorządowej. Na przykład w lipcu 2013 r. wniosek o upadłość zgłosiło Detroit w przeszłości drugie najbogatsze miasto Stanach Zjednoczonych, symbol potęgi przemysłowej. W grudniu 2013 r. sąd orzekł, że miasto jest niewypłacalne.

${ }^{4}$ Badanie ankietowe przeprowadzono w dwóch etapach (etap I w pierwszym półroczu 2013 r., etap II w pierwszym półroczu 2014 r.) na grupie 1560 osób.

${ }^{5}$ Ustawa z 27 sierpnia 2009 r. o finansach publicznych. DzU nr 157, poz. 1240, ze zm.

${ }^{6}$ Komunikat nr 6 Ministra Finansów z 6 grudnia 2012 r. w sprawie szczegółowych wytycznych dla sektora finansów publicznych w zakresie planowania i zarządzania ryzykiem. Dziennik Urzędowy Ministra Finansów 2012 poz. 56.
} 
Zazwyczaj w literaturze przedmiotu pojęcia niepewności i ryzyka opisywane są razem. Dlatego zapewne w załączniku do Komunikatu nr 6 Ministra Finansów z 6 grudnia 2012 r. w sprawie szczegółowych wytycznych dla sektora finansów publicznych w zakresie planowania i zarządzania ryzykiem zostało umieszczone następujące stwierdzenie „Realizacja ustalonych celów i zadań zawsze obciążona jest niepewnością tj. ryzykiem”. Trzeba jednak zaznaczyć, że chociaż w języku potocznym obydwa terminy często są wykorzystywane zamiennie i dotyczą tych samych zjawisk, to mają różne znaczenia. Dotyczą one bowiem chronologicznie następujących po sobie faz tego samego procesu decyzyjnego ${ }^{7}$. Zasadnicza różnica między ryzykiem a niepewnością dotyczy również ilości i jakości informacji na temat omawianych zjawisk.

Niepewność ${ }^{8}$ definiowana jest jako brak informacji o przyszłych zdarzeniach, nieprzewidywalność utrudniająca określenie wariantów działania, ich skutków i dokonanie wyboru'. Jest to możliwe odchylenie od stanów oczekiwanych, którego nie można przewidzieć i kwantyfikować ${ }^{10}$. Zjawisko to określane jest nawet „poziomem niewiedzy”" Występuje ono w momencie, gdy mamy nieadekwatną wiedzę o zdarzeniu, które wymaga podjęcia jakiegoś działania lub rozwiązania jakiegoś problemu ${ }^{12}$.

Z drugiej strony ryzyko jest definiowane odmiennie w zależności od obszaru sytuacji decyzyjnej i sposobu jego analizy. Frank H. Knight, twórca mierzalnej i niemierzalnej teorii niepewności, twierdzi, że ryzyko jest niczym innym jak niepewnością mierzalną ${ }^{13}$. Zatem można przyjąć, że ryzyko stanowi szczególny przypadek niepewności, który można określić wartością liczbową.

Natomiast w teorii zarządzania ryzyko zazwyczaj definiowane jest jako możliwość nieosiągnięcia założonego celu. W taki sposób definiuje je Anton Schmoll, twierdząc, że jest to niebezpieczeństwo negatywnego odchylenia od celu ${ }^{14}$. Według A. Ehrlicha jest ono rozumiane jako możliwość nieuzyskania zamierzonych efektów, poniesienia niezamierzonych strat lub nakładów wyższych od przewidywanych ${ }^{15}$. Z kolei E. Kleim dowodzi, że ryzyko $w$ sytuacji niepełnej informacji prowadzi do podejmowania decyzji nieoptymalnych $\mathrm{z}$ punktu widzenia założonego celu $^{16}$. W właśnie tym duchu wywodzącym się

${ }^{7}$ Szerzej zob. K. Jędralska, Zachowania przedsiębiorstw w sytuacjach niepewnych i ryzykownych, Wydawnictwo AE w Katowicach, Katowice 1992, s. 54.

${ }^{8}$ Szerzej na temat problematyki niepewności zob. M. Sołtysiak, Niepewność jako element procesów gospodarczych, „Zeszyty Naukowe Politechniki Rzeszowskiej” 260, „Zarządzanie i Marketing Kwartalnik” 16/3 (2009).

Należy podkreślić, że niepewność jest pojęciem wieloznacznym trudnym do precyzyjnego zdefiniowania. Irving Pfeffer twierdzi, że wynika to $\mathrm{z}$ tego, że jest ona stanem umysłu mierzonym przez poziom wiary. Szerzej zob. I. Pfeffer, Insurance and Economic Theory. Irvin Inc., Homewood, Illinois 1956, s. 42.

${ }^{9}$ A.K. Koźminski, W. Piotrkowski, Zarzqdzanie. Teoria i praktyka, PWN, Warszawa 1998, s. 765.

${ }^{10}$ Szerzej zob. F.H. Knight, Risk, Uncertainty and Profit, University on London, London 1921.

${ }^{11} \mathrm{~W}$ ten sposób niepewność określa I. Fischer. Szerzej zobacz P. Jedynak, Polityka ubezpieczeń w przedsiębiorstwie, Wydawnictwo Uniwersytetu Jagiellońskiego, Kraków 1999, s. 14.

${ }^{12}$ F. Landy, J.C. Quick, S. Kasl, Work, Stress, and Well-Being, ,International Journal of Stress Management” 1994/1.

${ }^{13}$ F.H. Knight, Risk, Uncertainty and Profit, University on London, London 1921.

${ }^{14}$ A. Schmoll, Risikomanagement in Kreditgeschäft. Wien 1993, s. 34.

${ }^{15}$ A. Ehrlich, Ryzyko gospodarcze, [w:] Encyklopedia organizacji i zarzadzania, PWE, Warszawa 1981, s. 456-457.

${ }^{16}$ Cyt. za: B. Gruszka, Z. Zawadzka, Ryzyko dziatalności bankowej, zabezpieczenia systemowe, Wydawnictwo SGH, Warszawa 1992, s. 9. 
z teorii zarządzania zostały opracowane definicje ryzyka, dla którego analizowanym obszarem jest działalność sektora administracji publicznej.

$\mathrm{W}$ podręczniku audytu wewnętrznego w administracji publicznej ryzyko jest definiowane jako prawdopodobieństwo wystąpienia dowolnego zdarzenia, działania lub braku działania, którego skutkiem może być szkoda w majątku bądź wizerunku danej jednostki lub które przeszkodzi w osiągnięciu wyznaczonych jej celów i zadań ${ }^{17}$.

W odniesieniu do jednostek samorządu terytorialnego w załączniku do Komunikatu nr 6 Ministra Finansów z 6 grudnia 2012 r. ryzyko zostało właśnie definiowane jako „możliwość zaistnienia zdarzenia, które negatywnie wpłynie na osiągnięcie celów i zadań”.

\section{RODZAJE RYZYKA W DZIAŁALNOŚCI JEDNOSTEK SAMORZĄDU TE- RYTORIALNEGO}

Klasyfikację ryzyka występującego w jednostkach samorządu terytorialnego, podobnie jak klasyfikację ryzyka odnoszącą się do podmiotów gospodarczych czy też do dowolnej działalności człowieka, należy rozpocząć od najbardziej ogólnego podziału na ryzyko systematyczne i ryzyko specyficzne.

Ryzyko systematyczne nazywane również ryzykiem ogólnym lub ryzykiem niedywersyfikowanym związane jest z oddziaływaniem sił zewnętrznych, na które nie ma wpływu jednostka samorządu terytorialnego. Źródeł tego ryzyka należy poszukiwać przede wszystkim w sytuacji społeczno-gospodarczej kraju, w sytuacji politycznej czy też w zmianach przepisów prawnych.

Ryzyko systematyczne nazywane również ryzykiem szczegółowym lub ryzykiem zdywersyfikowanym wynika ze specyfiki funkcjonowania danej jednostki samorządu terytorialnego. Jednostka samorządowa ma możliwość wpływania na wielkość tego ryzyka, którego źródła mogą być związane między innymi z finansami jednostki, jej systemem zarządzania czy działalności zatrudnionego w niej personelu.

W przeprowadzonych badaniach 87,26\% ankietowanych wskazało, że działalność jednostek samorządowych jest zagrożona występowaniem łącznie dwóch rodzajów ryzyka (ryzyka systematycznego i ryzyka specyficznego), 12,26\% ankietowanych wskazało tylko ryzyko systematyczne, a tylko $0,48 \%$ ankietowanych wskazało wyłącznie ryzyko specyficzne.

Przyjmując jako kryterium klasyfikacji ryzyka źródła jego pochodzenia, można wyróżnić ryzyko wewnętrzne i ryzyko zewnętrzne. Zdaniem ankietowanych większy wpływ na działalność jednostki samorządu terytorialnego ma ryzyko zewnętrzne (taką odpowiedź wybrało ponad $73 \%$ ankietowanych).

Na ryzyko zewnętrzne składa się między innymi ryzyko naturalne ${ }^{18}$, ryzyko społeczno-gospodarcze ${ }^{19}$, ryzyko polityczne, ryzyko prawne oraz ryzyko infrastrukturalne. Re-

\footnotetext{
${ }^{17}$ Podręcznik audytu wewnętrznego w administracji publicznej, Ministerstwo Finansów, Warszawa 2003, www.mf.gov.pl, s. 21.

W podobnym duchu ryzyko definiują Międzynarodowe Standardy Profesjonalnej Praktyki Zawodowej Audytu Wewnętrznego. Definiują one ryzyko jako możliwość zaistnienia zdarzenia, które będzie miało wpływ na realizację założonych celów. Międzynarodowe Standardy Profesjonalnej Praktyki Zawodowej Audytu Wewnętrznego, Załącznik do komunikatu nr 8 Ministra Finansów z 20 kwietnia 2010 r. w sprawie standardów audytu wewnętrznego w jednostkach sektora finansów publicznych (Dz. Urz. Min. Fin. z 2010 r., nr 5, poz. 24).

${ }^{18}$ Ryzyko naturalne wynika z zagrożeń związanych z oddziaływania sił natury.
} 
spondenci określili w ramach ryzyka zewnętrznego następującą hierarchię ważności: ryzyko prawne $(34,44 \%)$, ryzyko polityczne $(29,3 \%)$, ryzyko społeczno-gospodarcze $(24,47 \%)$, ryzyko infrastrukturalne $(9,67 \%)$, ryzyko naturalne $(2,11 \%)$.

Ryzyko wewnętrzne związane jest bezpośrednio $\mathrm{z}$ funkcjonowaniem danej jednostki samorządu terytorialnego. W ramach tego ryzyka można wyróżnić: ryzyko finansowe, ryzyko personelu, ryzyko systemu zarządzania, ryzyko techniczne. Respondenci określili w ramach ryzyka wewnętrznego następującą hierarchię ważności: ryzyko finansowe (81\%), ryzyko personelu $(13,6 \%)$, ryzyko systemu zarządzania $(4,5 \%)$, ryzyko techniczne $(0,9 \%)$.

Szczegółowe klasyfikacje ryzyka występującego w jednostkach samorządu terytorialnego powinny być opracowywane w odniesieniu do specyfiki działania konkretnej jednostki. Ministerstwo Finansów zaproponowało następującą klasyfikację na podstawie kryterium możliwych źródeł przyczyn oraz skutków $w^{20}$ :

Ryzyko finansowe:

- ryzyko budżetowe;

- ryzyko oszustwa i kradzieży;

- ryzyko podlegające ubezpieczeniu;

- ryzyko zamówień publicznych i zlecenia zadań publicznych;

- ryzyko odpowiedzialności.

Ryzyko dotyczące zasobów ludzkich:

- ryzyko personelu;

- ryzyko BHP.

Ryzyko działalności:

- ryzyko regulacji wewnętrznych;

- ryzyko organizacji i podejmowania decyzji;

- ryzyko kontroli wewnętrznej;

- ryzyko informacji;

- ryzyko wizerunku;

- ryzyko systemów informacyjnych.

Ryzyko zewnętrzne:

- ryzyko infrastrukturalne;

- ryzyko gospodarcze;

- ryzyko środowiska prawnego;

- ryzyko środowiska politycznego.

\section{ZARZĄDZANIE RYZYKIEM W JEDNOSTKACH SAMORZĄDU TERYTO- RIALNEGO}

Dynamiczny rozwój zarządzania ryzykiem jest notowany od drugiej połowy XX wieku. W początkowym okresie utożsamiany był jedynie z elementami zarządzania ubezpieczeniami. Wraz z pojawianiem się nowych rodzajów ryzyka zwiększał się również zakres zarządzania ryzykiem, które obejmowało coraz to nowe dziedziny.

\footnotetext{
${ }^{19}$ Ryzyko społeczno-gospodarcze związane jest z czynnikami natury ekonomicznej, na przykład inflacja, kursy walut itp.

${ }^{20}$ Załącznik do załącznika do Komunikatu nr 6 Ministra Finansów z 6 grudnia 2012 r.
} 
W uniwersalny sposób dyscyplinę tę zdefiniował Emmett J. Vaughan, twierdząc, że zarządzanie ryzykiem jest naukowym podejściem do postępowania z poszczególnymi rodzajami ryzyka przez odgadywanie i uprzedzanie możliwych przypadkowych strat oraz przez projektowanie i wprowadzanie procedur, które minimalizują występowanie straty lub rekompensują finansowo straty, jeśli się zdarzą ${ }^{21}$.

Natomiast Międzynarodowe Standardy Profesjonalnej Praktyki Audytu Wewnętrznego definiują zarządzanie ryzykiem jako proces identyfikacji, oceny, zarządzania i kontroli potencjalnych zdarzeń lub sytuacji zmierzających do dostarczenia racjonalnego zapewnienia, że cele organizacji zostaną zrealizowane ${ }^{22}$.

Obecnie proces ten jest realizowany praktycznie we wszystkich sferach aktywności człowieka. Na początku XXI w. objął swoim zasięgiem również jednostki samorządu terytorialnego ${ }^{23}$. Proces zarządzania ryzykiem powinien być integralną częścią procesu zarządzania jednostką samorządu terytorialnego. Należy jednak zaznaczyć, że w lokalnych społecznościach zdania na ten temat sa podzielone. Wyniki przeprowadzonych badań ankietowych wykazały, że niespełna 53\% respondentów uważało, że taki system powinien zostać wdrożony w jednostkach samorządowych ${ }^{24}$. Jeszcze mniej bo niespełna $29 \%$ ankietowanych było zdania, że w jednostkach tych powinno się stworzyć osobną komórkę organizacyjną odpowiedzialną za zarządzanie ryzykiem.

Pamiętając, że misją jednostek samorządu terytorialnego jest zaspokajanie zbiorowych potrzeb lokalnych społeczności oraz że ryzyko związane z działalnością jednostek samorządu terytorialnego zazwyczaj utożsamiane jest z możliwością pojawienia się określonych negatywnych zjawisk (strat, konieczności poniesienia dodatkowych kosztów itp.), należy brać pod uwagę, że proces zarządzania ryzykiem realizowany w tych jednostkach powinien być nakierowany przede wszystkim na zapewnienie im bezpieczeństwa oraz stabilności działania. Tak więc jego podstawowym celem powinno być podjęcie działań monitorujących oraz zapobiegających ewentualnym negatywnym skutkom społecznogospodarczym. Realizacja tego procesu powinna pozwolić na wykrycie miejsc narażonych na występowanie zagrożeń oraz podjęcie działań mających na celu ich minimalizację, które w dłuższym czasie pozwoliłyby na osiągnięcie założonych przez jednostkę celów. Ponadto wdrożenie w jednostce samorządowej systemu zarządzania ryzykiem ma na celu udoskonalenie jej metod działania, w tym przede wszystkim procesów podejmowania decyzji w zakresie gospodarowania środkami publicznymi, oraz poprawę jakości świadczonych przez nią usług lokalnym społecznościom.

W związku z tym Minister Finansów, nakładając w 2012 r. na lokalne samorządy podjęcie działań związanych $\mathrm{z}$ zarządzaniem ryzykiem, następująco określił definicję tego procesu: „Zarządzanie ryzykiem to procedury i polityki oraz skoordynowane działania, podejmowane zarówno przez kierownictwo jednostki, jak i jej pracowników, które po-

\footnotetext{
${ }^{21}$ Szerzej zob. E.J. Vaughan, Risk Management. J.Wiley\&Sons Inc. New York 1997.

${ }^{22}$ Międzynarodowe Standardy Profesjonalnej Praktyki Audytu Wewnętrznego, s. 20, Załącznik do Komunikatu nr 1 Ministra Finansów z 19 lutego 2009 r., Dziennik Urzędowy Ministerstwa Finansów nr 2, poz. 12.

${ }^{23}$ Znowelizowana „Ustawa z 26 listopada 1998 r. o finansach publicznych” nałożyła na audytorów wewnętrznych 1 stycznia 2002 r. obowiązek sporządzania rocznego planu audytu, który ma zawierać analizę obszarów ryzyka w zakresie gromadzenia środków publicznych i dysponowania nimi.

${ }^{24} \mathrm{Na}$ pytanie: „Czy zdaniem Pani/a w jednostkach samorządu terytorialnego powinien być stworzony system zarządzania ryzykiem" $9 \%$ ankietowanych odpowiedziało zdecydowanie tak, 43,68\% - raczej tak, 33,43\% raczej nie, $11,97 \%$ - zdecydowanie nie.
} 
przez identyfikację $\mathrm{i}$ analizę ryzyka oraz określanie adekwatnych reakcji na ryzyko zwiększają prawdopodobieństwo osiagnięcia celów i realizacji zadań,"25.

Proces wdrożenia i funkcjonowania systemu zarządzania ryzykiem $w$ jednostkach samorządu terytorialnego realizowany jest $\mathrm{w}$ ramach czteroetapowego cyklu ${ }^{26},{ }^{27}$ składającego się z:

- planowania - w ramach tego etapu przeprowadzona jest $\mathrm{z}$ jednej strony analiza funkcjonowania jednostki samorządu terytorialnego, $\mathrm{z}$ drugiej zaś analiza otoczenia, w jakim ona funkcjonuje. Na podstawie tych analiz następuje opracowanie projektu systemu zarządzania ryzykiem dostosowanego do specyficznych warunków funkcjonowania danej jednostki;

- wdrażania - w ramach tego etapu prowadzone są działania mające na celu zapoznanie pracowników jednostki z zagadnieniami związanymi z ryzykiem oraz opracowanym systemem zarządzania ryzykiem w jednostce. Efektem końcowym tego etapu jest włączenie systemu zarządzania ryzykiem do globalnego systemu zarządzania jednostką samorządu terytorialnego;

- monitorowania - w ramach tego etapu następują monitorowanie zjawisk wpływających na skuteczność funkcjonowania jednostki oraz ocena poprawności funkcjonowania systemu zarządzania ryzykiem;

- działania - w ramach tego etapu na podstawie informacji zebranych $w$ trakcie realizacji monitorowania podejmowane są decyzje dotyczące zasad funkcjonowania jednostki, które pozwolą na minimalizacje zagrożeń związanych z jej działalnością przez podjęcie działań mających na celu modyfikację opracowanego systemu zarządzania ryzykiem.

Do podstawowych korzyści związanych z wprowadzeniem w jednostkach samorządu terytorialnego systemu zarządzania ryzykiem należy zaliczyć:

- możliwość wskazania podstawowych rodzajów ryzyka, które mogą występować w działalności jednostki samorządu terytorialnego;

- możliwość oszacowania prawdopodobieństwa wystąpienia poszczególnych rodzajów ryzyka;

\footnotetext{
${ }^{25}$ Załącznik do Komunikat nr 6 Ministra Finansów z 6 grudnia 2012 r. w sprawie szczegółowych wytycznych dla sektora finansów publicznych w zakresie planowania i zarządzania ryzykiem. Dziennik Urzędowy Ministra Finansów 2012, poz. 56.

${ }^{26}$ Ibidem, s. 31.

${ }^{27}$ Propozycja Ministerstwa Finansów nie pokrywa się z wprowadzoną w 2000 r. przez Standards Committee Project Management Institute metodyką zarządzania ryzykiem składającą się z sześciu podstawowych etapów:

- planowanie procesu zarządzania ryzykiem - w ramach tego etapu tworzy się infrastrukturę i opracowuje plan zarządzania ryzykiem dla konkretnego projektu;

- identyfikacja ryzyka - stanowi opis zdarzeń, które mogą mieć potencjalnie negatywny wpływ na realizacje projektu;

- klasyfikacja ryzyka - ocena ryzyka za pomocą metod nienumerycznych;

- pomiar ryzyka - stanowi ocenę prawdopodobieństwa oraz skutków najważniejszych rodzajów ryzyka za pomocą parametrów liczbowych;

- planowanie sposobów reagowania na ryzyko - ocena i komunikacja strategii neutralizowania lub zapobiegania ryzyku;

- nadzorowanie i kontrola ryzyka - dotyczy metod zarządzania ryzykiem i planowanych sposobów reagowania na ryzyko.

Zob. C.L. Pritchard, Zarzadzanie ryzykiem w projektach. Teoria i praktyika, WIG-Press, Warszawa 2001, s. 4.
} 
- możliwość oszacowania wpływu poszczególnych rodzajów ryzyka na osiągnięcie założonych przez jednostkę samorządu terytorialnego celów oraz realizację zadań;

- możliwość opracowania procedur postępowania dotyczących poszczególnych rodzajów ryzyka;

- możliwość monitorowania zagrożeń realizacji celów oraz zadań jednostki samorządu terytorialnego na bieżąco.

Znaczenie zarządzania ryzykiem w jednostkach samorządu terytorialnego jest wprost proporcjonalne do założonych celów oraz realizowanych zadań, których osiągnięcie może być zagrożone. Proces ten powinien być każdorazowo dostosowany do specyfiki danej jednostki samorządu terytorialnego. Nie może być on traktowany jedynie jako zadanie, które samorząd musi zrealizować na mocy obowiązujących przepisów, lub jako przydatny element $\mathrm{w}$ procesie zarządzania jednostką. Nie należy go również utożsamiać z przeprowadzaną w określonych odstępach czasu kontrolą działalności jednostki ${ }^{28}$. Powinien się on stać jednym z podstawowych elementów systemu zarządzania (nie tylko w zakresie zagadnień finansowych), którego funkcjonowanie w jednostce będzie odbywało się w sposób ciągły poprzez stworzenie odpowiedniego zespołu i wskazanie pracowników odpowiedzialnych za monitorowanie ryzyka.

\section{PODSUMOWANIE}

Ryzyko jest nierozłącznym elementem działalności jednostek samorządu terytorialnego. Należy go zaliczyć do ważnych, choć równocześnie nie do końca rozpoznanych problemów występujących w funkcjonowaniu współczesnego samorządu. Jego skala i determinanty wynikają ze specyfiki funkcjonowania sektora publicznego.

Proces zarządzania ryzykiem w tych jednostkach jest zjawiskiem stosunkowo nowym, które pojawiło się kilka lat temu wraz z wprowadzeniem odpowiednich wymogów prawnych $^{29}$. Wdrażanie tego procesu może napotykać pewne braki zrozumienia wynikające z dwóch podstawowych przyczyn. Po pierwsze, podstawowy cel realizacji tego procesu jest inny niż w jednostkach gospodarczych. Po drugie, wiele osób nadal nie zauważa występowania ryzyka w działalności jednostek samorządu terytorialnego, a tym samym - konieczności wdrożenia systemu zarządzania ryzykiem. A jeżeli jest już ono dostrzegane, to zazwyczaj uważa się, że jest ono znacznie ograniczone w porównaniu z ryzykiem występującym w działalności podmiotów gospodarczych i odnosi się prawie wyłącznie do finansowej sfery ich działalności. Potwierdzeniem tego są uzyskane wyniki badań ankietowych: ponad $66 \%$ spośród respondentów, którzy wskazali odpowiedź, że z działalnością jednostek samorządu terytorialnego związane jest ryzyko - stwierdziło, że głównym rodzajem tego ryzyka jest ryzyko finansowe ${ }^{30}$. Dodatkowo należy zaznaczyć, że nie tylko przedstawiciele lokalnych społeczności odnoszą się sceptycznie do konieczności wdrożenia systemu zarządzania ryzykiem w jednostkach samorządowych. Postawę taką prezentuje również część kadry kierowniczej tych jednostek, twierdząc, że do podjęcia określonych działań w tym zakresie zmusiły ich nie tyle ewentualne korzyści, jakie może przy-

\footnotetext{
${ }^{28}$ Do celów kontroli zarządczej należy między innymi zapewnienie skuteczności procesu zarządzania ryzykiem.

${ }^{29}$ Do końca 2009 r. nie istniały przepisy prawne, które nakładałyby na jednostki samorządu terytorialnego obowiązek podejmowania działań w zakresie ryzyka związanego ze zrealizowanymi przez nie zadaniami.

${ }^{30} \mathrm{Na}$ kolejnych miejscach ankietowani wskazali: ryzyko polityczne $(14,2 \%)$, ryzyko prawne $(13,9 \%)$, ryzyko personelu $(5,74 \%)$.
} 
nieść wdrożenie systemu, ale wymogi prawne. Niepokojące stwierdzenia tego rodzaju mogą świadczyć o posiadaniu zbyt niskiego poziomu wiedzy w tym zakresie w grupie osób odpowiedzialnych za wdrażanie systemu.

Kolejnym istotnym problemem związanym z wdrożeniem systemów zarządzania ryzykiem w jednostkach samorządowych jest brak sprawdzonych wzorcowych rozwiązań systemowych, które tylko przy niewielkich modyfikacjach mogłyby być wykorzystywane przez wszystkie tego rodzaju podmioty. Dlatego wydaje się zasadne podjęcie próby wykorzystania doświadczeń zagranicznych oraz dostosowania istniejących standardów opracowanych dla podmiotów gospodarczych na potrzeby jednostek samorządowych.

Reasumując, należy stwierdzić, że w czasach dynamicznych zmian następujących w otoczeniu wydaje się, że jednostki samorządowe nie mają innego wyboru, jak stworzyć odpowiednie komórki odpowiedzialne za realizację procesu zarządzania ryzykiem. Działania takie nie powinny wynikać z obowiązujących przepisów prawnych, ale z chęci uniknięcia potencjalnych zagrożeń, których skutki bezpośrednio odczuwają lokalne społeczności. Ponadto należy udoskonalać systemy zarządzania, co w konsekwencji doprowadzi do udoskonalenia już posiadanych systemów zarządzania, a dzięki temu podniesie się jakość świadczonych usług.

\section{LITERATURA}

[1] Ehrlich A., Ryzyko gospodarcze, [w:] Encyklopedia organizacji i zarzadzania, PWE, Warszawa 1981.

[2] Jedynak P., Polityka ubezpieczeń w przedsiębiorstwie, Wydawnictwo Uniwersytetu Jagiellońskiego, Kraków 1999.

[3] Jędralska K., Zachowania przedsiębiorstw w sytuacjach niepewnych i ryzykownych, Wydawnictwo AE w Katowicach, Katowice 1992.

[4] Knight F.H., Risk, Uncertainty and Profit, University on London, London 1921.

[5] Koźminski A.K., Piotrkowski W., Zarzadzanie. Teoria i Praktyka, PWN, Warszawa 1998.

[6] Landy F., Quick J.C., Kasl S., Work, Stress, and Well-Being, „International Journal of Stress Management" 1994/1.

[7] Ocena sytuacji samorzqdów lokalnych, Ministerstwo Administracji i Cyfryzacji, http://m.mac.gov.pl/files/ocena-sytuacji-samorzadow-lokalnych.pdf.

[8] Ustawa z 27 sierpnia 2009 r. o finansach publicznych (DzU nr 157, poz. 1240, ze zm.

[9] Komunikat nr 6 Ministra Finansów z 6 grudnia 2012 r. w sprawie szczegółowych wytycznych dla sektora finansów publicznych w zakresie planowania i zarządzania ryzykiem. Dziennik Urzędowy Ministra Finansów 2012, poz. 56.

[10] Międzynarodowe Standardy Profesjonalnej Praktyki Zawodowej Audytu Wewnętrznego, Załącznik do komunikatu nr 1 Ministra Finansów z 19 lutego 2009 r., Dziennik Urzędowy Min. Fin. z 2009 r., nr 2, poz. 12.

[11] Międzynarodowe Standardy Profesjonalnej Praktyki Zawodowej Audytu Wewnętrznego, Załącznik do komunikatu nr 8 Ministra Finansów z 20 kwietnia 2010 r. w sprawie standardów audytu wewnętrznego w jednostkach sektora finansów publicznych, Dziennik Urzędowy Min. Fin. z 2010 r., nr 5, poz. 24.

[12] Pfeffer J., Insurance and Economic Theory, Irvin Inc., Homewood, Illinois 1956.

[13] Pritchard C.L., Zarzqdzanie ryzykiem w projektach. Teoria i praktyka, WIG-Press, Warszawa 2001.

[14] Podręcznik audytu wewnętrznego w administracji publicznej, Ministerstwo Finansów, Warszawa 2003, www.mf.gov.pl.

[15] Schmoll A., Risikomanagement in Kreditgeschäft, Wien 1993. 
[16] Sołtysiak M., Niepewność jako element procesów gospodarczych, „Zeszyty Naukowe Politechniki Rzeszowskiej” 260, „Zarządzanie i Marketing Kwartalnik” 16/3 (2009).

[17] Sołtysiak M., Wprowadzenie do teorii skutecznego zarzadzania ryzykiem, [w:] Dylematy zarzadzania organizacjami we wspótczesnej gospodarce, red. A. Adamik, S. Lachiewicz, Wydawnictwo Politechniki Łódzkiej, Łódź 2010.

[18] Vaughan E.J., Risk Management, J. Wiley \& Sons Inc., New York 1997.

\section{RISK AND RISK MANAGEMENT IN LOCAL GOVERNMENT UNITS}

For centuries uncertainty and risk have been inherent in human activity in private and economic spheres. They became the subject of detailed studies in a variety of scientific disciplines one century ago. Originally the main research was related to risk in business activity. Until now, majority of people identify the risk right there.

In the literature several risk definitions are found depending on a decision-making situation and the analysis method. Thus, according to the management theory, risk can be defined as the possibility of not achieving the assumed goal. In the USA a new scientific discipline known as risk management emerged in the 20th century. Initially, it was only treated as a part of insurance management. More recently the risk management, as focused on reducing uncertainty, has been seen as the process inextricably linked to almost all spheres of human activity. Surprisingly enough, it was only local government activities that were not explored from such perspective till the early 21 st century.

The article presents issues related to risk in local government units. In Poland, managing risk in local governments has become the subject of detailed studies more recently due to the introduction of law imposing some risk management activities on local government units. Previously, the local government units were obliged merely to minimizing financial risk by implementing standards and systemic approach to management control.

The first part of the paper presents the definition and typology of risk in local governments. Next, it provides the issues related to risk management in these entities.

Keywords: risk, risk management, local government units

DOI: 10.7862/rz.2014.mmr.57

Tekst złożono w redakcji: wrzesień 2014

Przyjęto do druku: listopad 2014 